\title{
The Hiring of Accounting and Finance Officers from Audit Firms: How did the Market React?
}

\begin{abstract}
The Sarbanes-Oxley Act (SOX) restricted the hiring of accounting and finance officers directly from a company's external audit firm, reflecting concerns that such "revolving door" appointments had impaired the quality of audited financial statements. However, it was also argued that companies may have benefited from hiring individuals already familiar with their systems, organization and personnel. To determine how shareholders viewed revolving door appointments, we examine three-day cumulative abnormal returns around the announcements of newly appointed accounting and finance officers. We find that the proportion of revolving door hires is low (only 6.1 percent of all hires in our sample) and that the market valued the revolving door appointments more positively than other appointments. Further tests reveal that the positive market reaction to revolving door appointments is driven mainly by smaller companies, and that revolving door appointments are not associated with higher levels of subsequent discretionary accruals and are negatively related to a company's subsequent receipt of an Accounting and Auditing Enforcement Release (AAER). Overall, the low frequency of occurrence, investors' positive perceptions, and the lack of association with deteriorated reporting quality indicate that the SOX restriction on revolving door appointments may do little to protect shareholders.
\end{abstract}

Classification codes: G38, M42

Key words: audit and reporting quality, revolving door, event study. 


\section{The Hiring of Accounting and Finance Officers from Audit Firms: How did the Market React?}

In several prominent accounting scandals (e.g., Enron, Cendant, Global Crossing, Phar-Mor and Waste Management), senior accounting and finance officers previously worked for their companies' external audit firms. These widely publicized cases led to the Sarbanes-Oxley Act (SOX 2002), which now restricts the hiring of accounting and finance officers directly from companies' external audit firms - the auditor-to-client hiring practice referred to as the "revolving door." The revolving door hiring practice was restricted because of concerns that such appointments threaten audit and financial reporting quality. To date, however, no study has examined the frequency with which companies hired accounting and finance officers directly from their audit firms as opposed to hiring from elsewhere. This is important because the potential threat to audit and financial reporting quality would have been more serious if the revolving door practice was commonplace. Moreover, prior studies have not investigated how shareholders viewed revolving door appointments. We investigate shareholders' perceptions by comparing the market's reaction to announcements of revolving door and non-revolving door appointments.

While there is some evidence that revolving door appointments may have impaired the quality of audited financial statements (Menon \& Williams, 2004; Lennox, 2005), the extant evidence is far from unanimous (Dowdell \& Krishnan, 2004; Geiger, North \& O'Connell, 2005; Geiger \& North, 2006). If revolving door appointments did impair the credibility of financial reporting, shareholders may have viewed revolving door appointments unfavorably, in which case the market reaction may have been negative. On the other hand, extant studies ignore the potential benefits that revolving door appointments may have brought to shareholders. For example, the former auditor may have been the company's most suitable job 
candidate because, having worked with the company, the auditor was familiar with the company's systems, personnel, and reporting issues. Moreover, auditors are privy to a substantial amount of internal company information, so an auditor's acceptance of employment may have signaled positive news about the company's future. Ultimately then, it is an empirical question whether shareholders viewed revolving door appointments positively or negatively. To the extent that the SOX interdict on revolving door appointments was intended to benefit shareholders, our event study methodology provides additional insight about the new legislation from the market's perspective.

We calculate cumulative abnormal returns (CAR) over three days $(-1$ to +1$)$ for public companies that announce the appointments of senior accounting and finance officers. We use these public announcements as a way to identify individuals that are hired directly from the company's external audit firm. In addition to revolving door appointments, we identify newly appointed officers who previously worked at other audit firms. This identification facilitates a test of whether the market reacts to revolving door appointments per se or to the hiring of someone who has prior CPA experience. To test whether the market reacts differently to appointments of officers with CPA experience, we also sample newly appointed officers who did not previously work for audit firms.

The sample period is from January 1985 to July 2002 (the date when SOX was passed) and consists of 3,176 newly-hired accounting and finance officers. Of these, we find that only 193 (6.1 percent) officers were hired directly from the company's own audit firm and the frequency of revolving door appointments was actually decreasing in the years leading up to SOX. Thus, revolving door appointments were not commonplace and the SOX restriction on such appointments would apparently not have had a big impact on hiring companies. We also find that the mean positive CAR for revolving door appointments is $+1.2 \%$, which is 
significantly greater than zero $(t$-statistic $=3.11)$. In contrast, we find no significant market reaction for non-revolving door appointments, regardless of whether the newly hired officers have or do not have prior CPA experience. Our multivariate tests indicate that the positive market reaction to revolving door hires remains significant after controlling for the officer's new job title (e.g., Chief Financial Officer), gender, CPA experience, former position at the audit firm (e.g., partner), the hiring company's size, age, profitability, leverage, growth opportunities and confounding disclosures. We conclude that the market responded positively when companies hired accounting/finance officers directly from their external audit firms. The low frequency of revolving door appointments and the market's positive reaction suggest that the SOX restriction on revolving door appointments may have been unnecessary, at least from the perspective of shareholders.

Next, we examine which companies experienced the largest positive market reactions to revolving door hires. In the Congressional debate leading to SOX, some commentators argued that a restriction on revolving door appointments would be particularly detrimental to small companies (Herdman, 2001; Pitt, 2002). Similarly, the Independence Standards Board (ISB) had earlier argued that small companies benefit the most from appointing the company's external auditors to employment positions (ISB, 1999). This is because smaller companies have fewer resources to search for officers and smaller companies are more closely tied to their external auditors for business and financial reporting advice. In addition, an auditor's decision to join a client may be a stronger positive signal when the client is small and less well known. Thus, we predict that the market reaction would have been more positive when auditors are hired by small companies rather than by large companies. To test this, we partition the appointments made by large and small companies using the median value of total assets. Among small companies, the market reaction is significantly positive for revolving door 
appointments and it is insignificant for non-revolving appointments. Among large companies, the market reaction is insignificant for both revolving door and other appointments. The multivariate results confirm that the aggregate positive market reaction to revolving door appointments is driven by the smaller companies. These findings are consistent with those who argued that small companies would suffer most from the SOX restriction on revolving door appointments.

While the market reacted positively to the revolving door appointments, it is nevertheless possible that the appointments reduced financial reporting quality. To examine the impact of revolving door appointments on the quality of financial reporting, we examine levels of signed discretionary accruals and the frequency with which companies received Accounting and Auditing Enforcement Releases (AAERs) following new officer appointments. If revolving door appointments impaired financial reporting quality, we expect that levels of discretionary accruals would he higher and AAERs would have been issued more often to companies that appointed officers from their own audit firms. With respect to levels of discretionary accruals, we find that signed discretionary accrual levels are not statistically different between our revolving door hiring firms and non-revolving door firms either in the year of appointment or in the subsequent reporting year. Within the full sample of 3,176 appointments, we find that 93 companies received AAERs within the following five years. Only $1(0.5 \%)$ company received an AAER following a revolving door appointment compared to $92(3.1 \%)$ companies that received AAERs following non-revolving door appointments. The difference between these frequencies $(0.5 \%$ versus $3.1 \%)$ is statistically significant, even after controlling for other firm and individual factors $(z-$ statistic $=-2.31)$. These findings do not support the view that revolving door appointments impaired the quality of financial reporting after they assumed their new responsibilities within the company. 
Our paper makes two contributions to the literature. First, the study responds to a call by DeFond and Francis (2005) for further evidence on the impact of revolving door appointments. Prior studies investigate the effect of revolving door appointments on earnings management and on the issuance of going concern opinions (Dowdell \& Krishnan, 2004; Geiger et al., 2005; Lennox, 2005; Menon \& Williams, 2004), but the evidence from these studies is mixed and, as discussed later, the samples used in some studies do not directly address the types of appointments targeted by SOX. In contrast, we present evidence on the prevalence of the revolving door hires that are now banned by SOX and their impact on shareholder wealth and the quality of financial reporting.

Second, the study contributes to evidence about the impact of SOX on shareholders. Motivated by the SOX requirement that companies disclose whether audit committee members are financial experts, DeFond, Hann, and $\mathrm{Hu}$ (2005) examine how the market reacts when directors with financial expertise are appointed to audit committees. Using a test period prior to SOX, they find that the market reacted positively to the appointments of accounting financial experts but the market did not react significantly to the appointments of non-accounting financial experts. Motivated by the SOX moratorium on revolving door appointments, our study reveals that revolving door appointments occurred infrequently in the pre-SOX period, the market reacted positively when they did occur, and there does not appear to be a significant reduction in the quality of financial reporting after these appointments. Thus, our results suggest that the SOX ruling may not be an effective protection for shareholders.

The next section provides a brief background, discusses the relevant literature and presents the hypotheses. Section 2 presents our sample selection procedures and descriptive statistics. Section 3 reports the main results and additional tests. Section 4 summarizes and discusses the study's findings. 


\section{Background, Literature and Hypotheses}

\subsection{Background}

The practice of hiring accounting and finance personnel from companies' external audit firms has long been a contentious issue because of concerns about the possible negative impact on audit and financial reporting quality (Mautz \& Sharf, 1961; AICPA, 1978; ISB, 1999). One potential problem is that an individual may not audit diligently the financial statements of a prospective employer, particularly if the individual and client are negotiating employment terms during the audit. ${ }^{1}$ Thus, the soon-to-be-hired individual may not act independently in the role as outside auditor. A second problem may arise after the auditor joins the client because the former auditor possesses an intimate understanding of the procedures used by their former audit firm to test the financial statements (e.g., knowledge of how the audit firm selects transactions for detailed testing, as well as the types and extent of tests performed on specific accounts). Additionally, former auditors may know personally many of the current auditors and they may have formerly been in a supervisory position over some, if not all, of their former colleagues (Clikeman, 1998; ISB, 2000). Such knowledge and personal relationships may afford former auditors the ability to influence the outcomes of the auditing process and the financial information reported (Beasley, Carcello \& Hermanson, 2000; Menon \& Williams, 2004).

Despite concerns that revolving door appointments impair financial reporting, the Independence Standards Board (ISB, 2000) formerly concluded that the hiring practice did not need to be restricted. In fact, the ISB stressed that the hiring of a knowledgeable individual

\footnotetext{
${ }^{1}$ If an auditor was approached by a client regarding an employment position, the AICPA required the auditor to withdraw from servicing the client until the employment issue was resolved. However, Kaplan and Whitecotton (2001) find that many auditors were unconcerned or unaware of the AICPA requirement and thus the auditors failed to comply.
} 
from a company's external audit firm may reassure investors that the financial statements are credible. The ISB (para. 13, 1999) stated that "limiting the ability of companies to hire qualified people will, in some cases, reduce the quality of financial reporting [. . .] these costs ultimately impinge on the degree of confidence investors can place in the securities markets." The revolving door hiring practice was eventually restricted only following several sizable accounting scandals in which financial reporting officers had previously been employed at their companies' external audit firms. Section 206 of the Sarbanes-Oxley Act (2002) forbids public companies from hiring their external auditors as senior accounting and finance officers for up to one year after the individual's departure from the audit firm. ${ }^{2}$ While similar employment restrictions had been debated and proposed in the past, the SOX restriction is the first to preclude auditors from stepping directly into senior financial reporting roles at their former clients.

\subsection{Prior Literature}

\subsubsection{Revolving door appointments and the quality of audited financial statements}

Following SOX, several archival studies have begun an examination of the impact of revolving door appointments on the quality of audited financial statements. Lennox (2005) measures audit quality by examining the frequency with which audit firms issue going-concern opinions. He identifies two situations in which officers previously worked for their companies' external audit firms: (1) an auditor leaves the audit firm to work for a client (i.e., a revolving door

\footnotetext{
${ }^{2}$ The Office of the Chief Accountant of the SEC has issued a clarification of how it intends to apply Section 206 in practice (SEC, 2003). Specifically, a member of the audit engagement team will be prohibited for one year from commencing employment in a financial reporting oversight role with the former client. The SEC has defined a "financial reporting oversight role" as one where a person is in a position to exercise influence over the contents of the financial statements or over anyone who prepares them (SEC, 2003). In addition to senior accounting and finance positions, SOX prohibits the hiring of CEOs from members of the audit team. Evidence reveals that, prior to SOX, auditors were typically hired into accounting or finance positions and they were very rarely hired as CEOs (e.g., Beasley et al., 2000; Lennox, 2005). Therefore, we collect data on accounting and finance appointments but not CEO appointments.
} 
appointment), (2) an officer persuades the company to appoint the officer's former audit firm (an "alma mater affiliation"). Consistent with audit quality being impaired, he finds that goingconcern audit opinions are issued less often if a company has an officer that previously worked for the company's external audit firm. While this finding is highly significant for alma mater affiliations, it is only weakly significant for revolving door appointments. Moreover, Lennox (2005) cautions that the revolving door results are potentially biased because auditors may have private information about their clients' future prospects and auditors may not join clients that are less likely to survive or get modified audit reports. This is an important caveat in the context of our study since the auditor's acceptance of an employment position may send a positive signal to the market about the auditor's confidence in the company's future.

Other studies test the effect on financial reporting quality by examining earnings management. In the first published study in this area, Menon and Williams (2004) identify both officers and directors who were former partners at their companies' audit firms. However, unlike Lennox (2005), they do not identify whether these affiliations arose as a result of revolving door appointments or alma mater affiliations. Menon and Williams (2004) find that affiliated companies have larger signed and unsigned abnormal accruals compared to companies where affiliations do not exist. They also find a disproportionately higher (lower) frequency of affiliated (unaffiliated) companies just meeting (missing) analysts' earnings forecasts. Thus, they conclude that affiliations between former partners and audit firms are associated with greater earnings management.

Our sample differs from Menon and Williams (2004) and Lennox (2005) in two important respects. First, their samples include both revolving door appointments and alma mater affiliations even though the SOX restriction applies only to revolving door hires. In contrast, our sample focuses upon revolving door appointments. Second, their samples include 
auditors who were initially appointed to junior positions, whereas our sample focuses on auditors who moved directly into senior management positions (e.g., Controller, Chief Financial Officer). Since the SOX restriction on the revolving door applies only to appointments of senior officers, our sample speaks more directly to the likely impact of SOX. Moreover, companies do not publicly announce the appointments of junior staff, so these appointments are not included in our event study.

Similar to our study and consistent with the SOX restriction, Dowdell and Krishnan (2004) and Geiger et al. (2005) focus specifically on revolving door appointments to senior corporate positions. Dowdell and Krishnan (2004) sample CFO appointments and their affiliated CFOs include not only former partners but also individuals who were employed at other ranks at audit firms. They find that signed abnormal accruals are higher for revolving door hires but they find no significant differences in absolute abnormal accruals. Since the SOX restriction applies to all influential accounting and finance positions (CFO, Chief Accounting Officer, Controller, Vice-President of Finance), the sample in Geiger et al. (2005) includes these other positions in addition to CFO. They find no significant difference in absolute accruals or non-operating accruals between the revolving door and the non-revolving door hiring companies.

More recently, Geiger and North (2006) examine changes in signed current discretionary accruals of companies hiring new CFOs. While not the main focus of the study, in a subsequent test they find that changes in discretionary accruals are not associated with whether the CFO was hired directly from the company's audit firm or from another external source. Thus, taken as a whole, the evidence is mixed as to whether the revolving door appointments targeted by SOX impaired the quality of audited financial statements. 


\subsubsection{Revolving door appointments and the benefits to hiring companies}

The extant literature primarily focuses on the potential costs of revolving door appointments, namely the potential threat to the credibility of audited financial statements (c.f., Menon \& Williams, 2004; Geiger et al., 2005). While such studies are important, they fail to account for certain benefits that companies may enjoy by hiring officers from their audit firms. One such benefit is detailed company-specific knowledge. External auditors are intricately familiar with the hiring company's business processes, information flows and reporting requirements. Thus, they are able to step into accounting and finance positions more effectively than individuals without such a detailed knowledge of the company and its reporting processes. ${ }^{3}$ When a company hires someone from its external audit firm, the company has had the chance to observe and work closely with the potential new officer prior to making the hiring decision. This extended relationship enables the hiring company to assess whether the new candidate interacts and works well with other company executives, and whether there is a "good fit" with the company and its culture (Beasley et al., 2000). Thus, a revolving door appointment may be preferable to hiring someone who is expected to be equally well-qualified but about whose organization fit there is greater uncertainty.

Additionally, since external auditors are privy to a substantial amount of internal company information, the company's ability to hire an external auditor may signal to shareholders and others that the auditor is confident enough in the company's future to accept an employment position. This is particularly salient if auditors receive employment offers from several client companies. Thus, an auditor's decision to join a specific client may provide a positive signal to the market regarding the future prospects of the hiring company.

\footnotetext{
${ }^{3}$ The ISB stressed that hiring qualified knowledgeable personnel from the company's external auditor may be beneficial to the company and the financial markets (ISB, 1999).
} 
In summary, the market reaction to a revolving door hire reflects the shareholders' joint assessment of: (1) any risks to the quality of audited financial statements, (2) the appointee's abilities and fit within the company, and (3) the appointment's signal about the company's future prospects. The net effect of these conflicting assessments is an empirical question that has not been formerly addressed.

\subsection{Hypotheses}

If shareholders believe that revolving door appointments threaten the quality of audited financial statements, the hiring firms may be perceived as more risky and this may result in a fall in their market values. Consistent with this view, Beasley et al. (2000) urge companies that are considering hiring executives from their audit firms to carefully evaluate their decision "given the potential for capital market participants to assign a negative signal to the hiring of an external auditor." On the other hand, the market may view a revolving door hire as a positive demonstration of the company's ability to attract a qualified individual who has relatively privileged inside information about the company. In this case we would expect a positive market reaction to the revolving door announcement. As noted earlier, the final net assessment by the market is an open empirical question and arguments have been marshaled on both sides. Since we cannot predict whether shareholders would view revolving door appointments positively or negatively, our first hypothesis is stated in null form:

$\mathrm{H}_{1}$ The market reaction is not significantly different between revolving door hires and non-revolving door hires. 
In Congressional hearings prior to the passing of SOX, it was claimed that any restrictions on revolving door appointments would be more detrimental to small companies (Herdman, 2001; Pitt, 2002). This sentiment of higher impact to smaller companies was also expressed in the ISB's exposure draft on revolving door hires (ISB, 1999). ${ }^{4}$ It was argued that smaller companies have fewer resources to search for new executives and they are more closely tied to their external auditors for business and financial reporting advice than are larger companies. Therefore, the benefit (or cost savings) of making a revolving door hire may be greater for small companies than for large companies and lead to higher abnormal returns. ${ }^{5}$

However, a larger positive reaction for small firms would not necessarily mean that small companies benefit more from revolving door hires. In particular, the positive signaling value of persuading an auditor to join a small company may be greater than that for a large reputable company. We expect that the market reaction to revolving door appointments is more positive (or less negative) for smaller firms, either because revolving door appointments confer greater benefits to smaller companies or because revolving door appointments are stronger positive signals. Therefore, our second hypothesis is stated in alternative form:

\section{$\mathrm{H}_{2}$ The difference in market reactions between revolving door hires and non-revolving} door hires is significantly more positive (or less negative) for small companies than for large companies.

\footnotetext{
4 The Independence Standards Board concluded (ISB, 1999, para. 37) that "a restriction on hiring former engagement partners or other professionals may be a heavier burden to smaller corporations in need of the accounting expertise provided by someone familiar with their business and industry, and to smaller firms. Smaller corporations may be at a disadvantage in recruiting personnel when competing with larger companies with strong national or regional name-recognition. Restricting these smaller companies from hiring directly from their audit firm (from among those who know the company well) may hurt them disproportionately."

${ }^{5}$ Even if the benefit is the same for small and large companies in dollar terms, the relative benefit may be greater for small companies because they have smaller market values to begin with. For example, an increase in value of $\$ 1$ million has a larger percentage impact on a company that is worth $\$ 10$ million than it has on a company that is worth $\$ 100$ million.
} 


\section{Sample Selection and Descriptive Statistics}

\subsection{Sample Selection}

We search the Dow Jones Interactive / Factiva databases for appointments of officers with the following job titles: "Chief Financial Officer", "CFO", "Controller", "Chief Accounting Officer", "CAO", "Treasurer" and "Vice President of Finance". We choose these titles because they are identified in SOX as the prohibited positions for revolving door appointments. We include stock exchange identifiers ("NYSE", "AMEX" or "NASDAQ") in the key word search to ensure that we search publicly traded companies. Finally, we combine these search terms with the following key words and their derivatives: "announce", "join", "hire” and "appoint". 6 We search for all new appointments in the pre-SOX period from January 1985 to July 2002. We choose a long sample period because, as demonstrated later, the frequency of revolving door appointments is low and we require a large sample to generate powerful tests. Using COMPUSTAT, we obtain financial statement data and we identify each company's external audit firm at the officer's appointment date. We collect returns data from the CRSP database. Consistent with Menon and Williams (2004), we restrict the sample to companies audited by Big Five firms or their predecessor firms for two reasons. First, the Big Five firms have more homogeneous reputations, so we expect that the market reaction is more consistent when auditors are hired from the Big Five. Second, we find only 18 revolving door appointments from non-Big Five firms, which is too few to reliably test for a differential market reaction between appointments from Big Five and non-Big Five firms. ${ }^{7}$

\footnotetext{
6 The words' derivatives are "announces", “announced”, “announcing”, “announcement”, “announcements", “joins”, “joining”, “joined”, "hires”, "hired”, "hiring”, “appoints”, “appointed”, “appointing”, "appointment” and "appointments".

${ }^{7}$ An untabulated test reveals that the mean CAR is $-1.20 \%$ for the 18 revolving door appointments from non-Big Five firms, which is not statistically significant $(t$-statistic $=-0.76)$.
} 
To identify the revolving door hires, we read each press announcement to determine whether the officer is hired directly from the company's own audit firm (the Appendix presents two press announcements as exhibits). The non-revolving door announcements include officers who previously worked for other Big Five audit firms and announcements that do not mention that the appointee previously worked for a Big Five firm. We sample both types of nonrevolving door appointments in order to test how the market reacts to the disclosure of CPA experience in the absence of the revolving door.

Our sample is similar to Mian (2001), who finds no significant market reaction in a sample of 2,227 CFO appointments. However, our sample consists of 3,176 appointments because we include other senior accounting and finance officers (e.g., Controller, VicePresident of Finance and Treasurer). In addition, Mian (2001) does not identify whether the individuals appointed to CFO had any prior CPA experience. Accordingly, he is unable to test whether the market reaction is significantly different between those with and without prior CPA experience, and is furthermore unable to assess differences between revolving door and non-revolving door hires.

\subsection{Descriptive statistics}

Table 1, Panel A shows there are 193 revolving door hires compared to 2,983 non-revolving door appointments from January 1985 to July 2002. Thus, only 6.1 percent of senior accounting and finance officers were hired directly from the company's own audit firm. This finding may be surprising because some authors suggest that revolving door appointments were fairly common (e.g., Mahoney \& Roush, 1994; Clikeman, 1998; Jubak, 2000; Wright, 2005). In contrast, our results indicate that the revolving door was not a common practice for the hiring of senior accounting and finance officers. Since the SOX restriction applies only to 
appointments of senior managers (not junior staff), the documented low frequency suggests that the SOX restriction may have little real impact. As far as we are aware, this study is the first to document the frequency with which auditors joined public company clients as senior accounting and finance officers. ${ }^{8}$

[TABLE 1 HERE]

Panel B of Table 1 also indicates that 1,141 (35.9\%) of the 3,176 newly-hired officers previously worked for Big Five audit firms (“CPA experience” hires). Panel C reports that 260 $(8.2 \%)$ newly hired officers were former partners at Big Five audit firms prior to their departure ("Partner" hires). Thus, most officers that have prior CPA experience left the audit firms without attaining the position of partner. This likely explains why so few auditors step directly into senior corporate positions. In other words, most revolving door hires are to junior corporate positions but such hires are not restricted by SOX. Panel D identifies the names of our sample companies' audit firms. A majority of companies were audited by PricewaterhouseCoopers or Ernst \& Young. ${ }^{9}$

Table 2 presents the distribution of the revolving door and non-revolving door samples by year. The overall number of officer appointments increases over time, which is consistent

\footnotetext{
${ }^{8}$ The Menon and Williams (2004) sample consists of 402 financial reporting officers who are former partners of their companies' audit firms. This is larger than our revolving door sample because their sample includes: (1) officers who did not join directly from the company's audit firm (i.e., non-revolving door appointments), and (2) appointments to junior positions within the company. For example, suppose the auditor joined a non-client company and then was subsequently hired by a company which was audited by the auditor's former firm; alternatively, suppose that the auditor joined the company in a junior position and subsequently became the company's CFO. In such cases, the auditor would be included in the Menon and Williams (2004) sample but excluded from our sample because the auditor was not appointed directly to a senior position. We focus upon direct appointments to senior positions because these are the revolving door appointments targeted by SOX.

${ }^{9}$ Within the entire sample, only 13 officers both worked for Arthur Andersen and joined companies between November 2001 and July 2002. Of these 13 appointments, only one officer is a revolving door hire. Thus, our results are not driven by Arthur Andersen staff leaving for positions with their clients after news of the Enron reporting scandal became public.
} 
with the increase in the number of announced CFO appointments reported in Mian (2002) and Geiger and North (2006). This increase may be attributable to greater media coverage over the sample period. The frequency of revolving door hires, however, declines in the latter half of the 1990s. This decline could reflect the public concerns about companies hiring officers from audit firms (ISB, 1999; Levitt, 1998). Alternatively, auditors may have had weaker incentives to leave the auditing profession following the Private Securities Litigation Reform Act (1995), which reduced the auditors' risk of litigation (Geiger \& Raghunandan, 2001). Whatever the reason, the prevalence of companies hiring individuals directly from their audit firms was relatively low and declining in the years immediately prior to the passage of SOX.

[TABLE 2 HERE]

\subsubsection{Cumulative abnormal returns (CARs)}

Following the standard event study methodology, we measure CARs over a three-day window beginning the day before the announcement through the day after. The three-day CAR is calculated as follows:

$C A R_{[-1,+1]}=\sum_{t=-1}^{t=+1} M A R_{t}$

where:

$M A R_{t}=\frac{1}{N_{t}} \sum_{i=1}^{N_{t}} A R_{i t}$ and $A R_{i t}=R_{i t}-E\left(R_{i t}\right)$ and $t=-1,0,+1$,

$R_{i t}=$ the return of company $i$ on day $t$, and

$E\left(R_{i t}\right)=$ the return of the value-weighted market portfolio on day $t$. 


\section{Results}

\subsection{Univariate tests}

In order to control for outliers, we first winsorize all the continuous variables at the $5 \%$ and 95\% percentiles. Table 3, Panel A shows that the mean CAR for the full sample is only $+0.2 \%$, which is statistically insignificant. This is consistent with the results reported in Mian (2001) who found no significant overall market reaction to new CFO appointments. However, the results are very different when we split the sample into revolving door and non-revolving door appointments. Panel B reports that the mean CAR for the revolving door hires is $+1.2 \%$, which is significantly greater than zero $(p$-value $=0.002)$. However, the mean CAR for the non-revolving door hires is $+0.1 \%$ and it is statistically insignificant ( $p$-value $=0.267$ ).

\section{[INSERT TABLE 3 HERE]}

To address the second hypothesis, we partition the revolving door hires into small and large companies using the median value of total assets in the full sample (\$205.20 million). ${ }^{10}$ As reported in Panel B of Table 3, the mean CAR for the revolving door hires is $+2.2 \%$ in small companies and it is highly significant $(p$-value $=0.001)$. In contrast, the mean CAR for the revolving door hires is only $+0.2 \%$ in large companies and it is statistically insignificant $(p-$ value $=0.646$ ). These findings are consistent with $\mathrm{H}_{2}$ and with the ISB's contention that smaller companies would be disproportionately penalized by the restriction on revolving door hires.

\footnotetext{
${ }^{10}$ The median asset size is $\$ 205.45$ million in the revolving door sample compared to $\$ 205.20$ million in the full sample. As reported in Panel B of Table 3, there are 97 revolving door hires by small companies (assets $<\$ 205.20$ million) and 96 revolving door hires by large companies (assets $>\$ 205.20$ million). Since the cutoffs of $\$ 205.20$ million and \$205.45 million are very similar, they both provide a near-equal split of the revolving door sample.
} 
To determine whether the positive market reaction to revolving door hires is really due to the revolving door, or just to appointments of individuals with Big Five experience, we examine whether the market reacts positively to the appointment of an officer with CPA experience. Panel $\mathrm{C}$ reports that the mean CAR is $+0.2 \%(p$-value $=0.171)$ for the 1,141 hires that have CPA experience compared to $+0.2 \%$ for the 2,035 hires without experience ( $p$-value $=0.233) .{ }^{11}$ Untabulated tests indicate that the market reactions of $+0.2 \%$ and $+0.2 \%$ are not significantly different. Additionally, the mean CARs for CPA experience and non-CPA experience range from $+0.1 \%$ to $+0.3 \%$ among large and small companies and none are significantly different from zero. Thus, the market does not provide a stock price reward to companies that just hire individuals with prior CPA experience. Taken together, these univariate results suggest that the market reacts positively to revolving door appointments, and this reaction is not driven by CPA experience per se.

\subsection{Multivariate tests}

\subsubsection{Tests of $H_{1}$}

To investigate whether the market reactions are driven by systematic differences between the revolving door and non-revolving door samples, we control for other factors in our multivariate tests. In these regressions, we assess the effect of revolving door hires on CARs after controlling for company-specific factors as well as characteristics of the individual. Companyspecific controls include those for financial health, growth opportunities, firm age and size. ${ }^{12}$ We control for financial health because the market may be more concerned about the

\footnotetext{
${ }^{11}$ Untabulated analyses also reveal that the mean CAR for the 948 non-revolving door hires with CPA experience is $+0.1 \%$, which is not significantly different from zero.

${ }^{12}$ Unless otherwise noted, our financial statement variables are taken from the financial statements immediately after the officer's appointment due to the unavailability of this data immediately prior to the appointment for several of the smaller companies in our sample.
} 
appointment of a new officer if the company is less financially healthy (Brickley, 2003). Thus, we include profitability (ROA) and level of financial debt (LEVERAGE) in our models and expect a positive association for ROA and a negative association for LEVERAGE. Additionally, an auditor may have stronger incentives to join a client that has good future growth prospects and the market's reaction to a new appointment may also be affected by the company's growth opportunities. We control for this possibility by using the book-to-market ratio, which is negatively related to the market's assessment of the company's growth potential (Gaver \& Gaver, 1993; Chang, Chen, Liao \& Mishra, 2006). The book-to-market variable $(B M)$ equals the book value of equity at the year-end divided by the company's market value at the end of the month preceding the announcement. It is also possible that the market's reaction to the hiring of a new financial reporting executive may be affected by the age of the company, so we account for this potential effect by including the age (AGE) of the hiring company as an additional control. We determine the age of the company as the number of years they have been listed on Compustat at the time of the hiring announcement. We also include a control for company size because we hypothesize that the market reaction to revolving door hires is significantly more positive (or less negative) for smaller companies $\left(\mathrm{H}_{2}\right)$. Our company size variable is the log of total assets $(\operatorname{Ln}($ ASSETS $)){ }^{13}$

Along with the company-specific controls, our regressions include controls for appointee characteristics that are disclosed in the press announcements. Specifically, we control for the title of the officer's new position (CFO or not), whether the officer had prior CPA experience with a Big Five firm (CPA_EXPERIENCE), whether the new individual was formerly a partner with a Big Five firm (PARTNER), and their gender (FEMALE). We include an indicator variable for the title of CFO because prior studies focus upon CFO appointments

\footnotetext{
${ }^{13}$ If we control for size using market capitalization rather than total assets the market reaction to revolving door hires remains significantly positive $(\mathrm{t}$-statistic $=2.00)$.
} 
(Mian, 2001; Geiger \& North, 2006) and because CFO is the most prevalent title among accounting and finance officers. Similarly, we include indicator variables for prior CPA experience and the former position of partner in order to control for the public accounting experience of the newly appointed executive. Farrell and Hersch (2005) argue that the market reaction may be more positive for female hires than for male hires if companies are perceived to be discriminating against women in their hiring decisions. Therefore, following Farrell and Hersch (2005), we include an indicator variable for the gender of the newly hired officer.

Table 4 presents a correlation matrix for all the independent variables. As would be expected, we find high positive correlations (i.e., above .30) between the CPA_EXPERIENCE, PARTNER and REVOLVING_DOOR variables. We also find high positive correlations between $\operatorname{Ln}($ ASSETS), $\operatorname{Ln}(A G E)$ and ROA, indicating that the larger companies in our study are also older and more profitable. However, none of these correlations are above .48 , and the correlations among the remaining variables are relatively low, and all are below .30.

\section{[INSERT TABLE 4 HERE]}

Table 5 presents the univariate comparisons of the independent variables between the revolving door and non-revolving door samples. As noted in the table, we find that the revolving door companies are significantly younger $(t$-statistic $=-3.70)$, have higher ROAs $(t-$ statistic $=3.26)$, have higher growth opportunities (i.e., lower mean $B M)(t$-statistic $=-2.43)$ and they are slightly less likely to title the new individual as CFO ( $t$-statistic $=-1.70)$ than the non-revolving door hiring companies. This suggests that auditors tended to join young clients that had good earnings and growth opportunities, consistent with the idea that a revolving door appointment may signal positive news about the company's future prospects. We find no 
systematic differences between the two samples with respect to size, amount of financial leverage, or the gender of the individual hired. Accordingly, we control for these firm and individual differences between the revolving door and non-revolving door hires in our multivariate regressions.

\section{[INSERT TABLE 5 HERE]}

The multivariate results are reported in Table 6 . The standard errors in the regressions are adjusted for the fact that some companies in our sample have multiple officer appointments during our 1985-2002 sample period. ${ }^{14}$ The results in column 1 indicate that the CARs for revolving door appointments are significantly more positive than the CARs of non-revolving door hires $(t$-statistic $=2.02, \mathrm{p}<.05)$. Therefore, the revolving door announcements elicited a larger positive reaction than did the announcements of non-revolving door hires, even after controlling for other factors associated with the hiring company or the individual. The regressions also indicate that ROA is positively related to the market reaction $(t$-statistic $=$ $2.66, \mathrm{p}<.01)$. This result suggests that the market reaction to appointing new financial reporting executives was more positive for more profitable companies. While the revolving door and ROA variables are significant, the other control variables are insignificant. ${ }^{15}$ The insignificant coefficients for CPA_EXPERIENCE and PARTNER indicate that, on average, the market did

\footnotetext{
${ }^{14}$ Within the sample as a whole, there are 1,806 companies with one appointment, 438 with two appointments, 112 with three appointments, 23 with four, 8 with five, 3 with six and 1 company with eight appointments. Within the revolving door sub-sample, there are 187 companies with one revolving door hire and 3 companies with two revolving door hires. As a sensitivity test, we estimate the models in Table 6 using the sub-sample of 1,806 companies that make just one appointment. In these reduced-sample regressions the REVOLVING_DOOR coefficient is positive and significant at $\mathrm{p}<.10(\mathrm{t}$-statistic $=1.76)$ and the REVOLVING_DOOR*SMALL coefficient is positive and significant at $\mathrm{p}<.05$ ( $\mathrm{t}$-statistic $=2.08)$.

${ }^{15}$ The insignificant FEMALE coefficient is consistent with evidence in Farrell and Hersch (2005) that the market does not value female and male appointments differently.
} 
not react to the officer's CPA experience or former position. In sum, these regression results suggest that the positive share price response is related to the announcement of a revolving door hire and not to other characteristics of the hired officers or of the hiring companies.

\section{[INSERT TABLE 6 HERE]}

Our finding of a positive market reaction to revolving door hires is particularly striking in light of earlier research that found no aggregate price reaction to new $\mathrm{CFO}$ appointments (Mian 2001). However, our study is the first to specifically examine the market reaction to revolving door announcements and our finding that there is a significant positive response is a valuable contribution in the assessment of this recently disallowed practice.

\subsubsection{Tests of $\mathrm{H}_{2}$}

To test whether the market reaction to revolving door hires is more positive for small companies, we create a small company dummy variable (SMALL) which equals one (zero) if total assets are less (greater) than the sample median (\$205.2 million). In column 2 of Table 6, we add the small company indicator variable (SMALL) and its interaction with the revolving door variable (REVOLVING_DOOR*SMALL). In this expanded regression, the coefficient on the interaction variable is positive and significant $(t$-statistic $=2.49, \mathrm{p}<.05) .{ }^{16}$ Therefore, consistent with $\mathrm{H}_{2}$, the market reacted more positively to revolving door appointments by small

\footnotetext{
${ }^{16}$ The SEC Advisory Committee on Small Public Companies defines "Smaller Companies" as those with less than $\$ 787.1$ million in market capitalization. If we use this market capitalization criterion instead of median asset size to indicate small companies in our sample, we obtain similar results. Specifically, the REVOLVING_DOOR*SMALL coefficient in the expanded regression remains positive and significant (t-statistic $=$ 1.87). Similarly, if we partition the sample using the median value of market capitalization ( $\$ 182.9$ million), the REVOLVING_DOOR*SMALL coefficient remains positive and significant $(\mathrm{t}$-statistic $=1.88)$.
} 
companies, even after controlling for other firm and individual characteristics. ${ }^{17}$ The results of our control variables are similar to column 1 . In sum, the results suggest that small public companies were rewarded by the market for hiring accounting and finance officers directly from their external audit firms. ${ }^{18}$ However, the SOX restriction means that this source of hiring financial reporting executives is no longer available.

\subsection{Revolving door hires and credible financial reporting}

The positive market reaction to revolving door hires captures the market's joint assessment of: (1) any possible impairment to the credibility of audited financial statements, (2) the qualities that the newly appointed officer brings to the company, and (3) a possible signal regarding the future prospects of the hiring company. While the net effect of these conflicting assessments is found to be positive, it can be argued that, nevertheless, the SOX restriction on revolving door hires was necessary to protect the credibility of audited financial statements. To assess this argument we provide additional evidence on the effect of revolving door appointments on the quality of financial statements.

\subsubsection{Abnormal accruals}

As previously noted, prior studies have examined the issuance of going-concern opinions (Lennox, 2005) and reported abnormal accruals (Menon \& Williams, 2004; Dowdell \&

\footnotetext{
${ }^{17}$ Alternatively, if we divide our samples into small firms and large firms and re-estimate the regression model in Column 1 of Table 6 for each of the sub-samples we obtain consistent results. Specifically, the positive market reaction to revolving door appointments is statistically significant for the small company regression $(\mathrm{p}<.05 ; t-$ statistic $=2.34)$, but it is insignificant for the large company regression $(t-$ statistic $=1.10)$. In addition, we find a significant positive reaction when small companies hire partners $(\mathrm{p}<.05 ; t-$ statistic $=2.71)$ but not when large companies hire partners $(t-$ statistic $=-1.72)$. Results of the other control variables are substantively the same as those reported in Column 1 of Table 6.

${ }^{18}$ Using a two day event window $(0$ to +1$)$ and a four-day event window $(-1$ to +2$)$ also produces similar results. The REVOLVING_DOOR*SMALL coefficient is positive and significant both for the two day event window ( $t$ statistic $=2.13)$ and for the four day event window $(t$-statistic $=2.35)$.
} 
Krishnan, 2004; Geiger et al., 2005) in order to determine whether revolving door hires impair financial reporting quality. However, the samples assessed in these studies are fairly disparate and may include hires that were not explicitly targeted by SOX. In order to provide additional, more direct evidence on the likely effects of SOX, we examine whether the sample of revolving door hiring firms subsequently report higher levels of discretionary accruals than do the non-revolving door hiring firms. If revolving door hires negatively impact the credibility of financial reporting, we would expect that firms hiring these individuals would report higher levels of signed discretionary accounting accruals (Menon \& Williams, 2004; Geiger \& North, 2006) after these new individuals assume their new roles.

Following prior research, we use the modified cross-sectional Jones (1991) model introduced by DeFond and Jiambalvo (1994) to calculate discretionary accruals. Predicted accruals for the firms in our study are estimated using the following model:

$A C_{i t} / T A_{i t-1}=\beta_{1}\left[1 / T A_{i t-1}\right]+\beta_{2}\left[\left[\Delta R E V_{i t}-\Delta A R_{i t}\right] / T A_{i t-1}\right]+\beta_{3}\left[P P E_{i t} / T A_{i t-1}\right]+e_{i t}$

where: $A C$ is our accruals measure defined as income before extraordinary items less operating cash flows adjusted for discontinued operations and extraordinary items (Hribar and Collins 2002), $T A$ is total assets, $\triangle R E V$ is change in revenue, $\triangle A R$ is change in accounts receivable, and PPE is property, plant and equipment, for firm $i$ at year $t$. We estimate the model crosssectionally using every firm in COMPUSTAT based on two-digit SIC industry groupings containing at least 10 firms, excluding the sample firm. The estimated coefficients from the 
industry regressions are used to predict accruals for the sample firms. Discretionary accruals $(D A)$ are then calculated as actual accruals minus the predicted accruals. ${ }^{19}$

We assess differences in $D A$ between our two hiring samples for the initial year of appointment, time $t$, and the year after the appointment, time $t+1$. For time $t$ (time $t+1)$ we are able to obtain data and calculate $D A$ for 143 (137) of the revolving door firms and 2,496 $(2,288)$ of the non-revolving door hiring firms. The mean DA for the revolving door firms at time $t$ (time $t+1)$ is $-3.04 \%(-3.34 \%)$ and for the non-revolving door firms is $-5.00 \%(-4.23 \%)$. While the revolving door firms report a higher mean $D A$ than the non-revolving door firms in both $t$ and $t+1$, separate $t$-tests reveal that the differences between the two hiring groups are not significant $(t-$ statistic $=1.30$ at time $t$, and 0.68 at time $t+1)$.

To further examine the differences in $D A$ among our two hiring groups we use a multivariate regression and include controls for other factors identified in prior research to be associated with levels of DA (e.g., Ashbaugh, LaFond, \& Mayhew, 2003; Becker, DeFond, Jiambalvo \& Subramanyam, 1998; Chung \& Kallapur, 2003; Menon \& Williams, 2004; Geiger \& North, 2006). Our model includes an indicator variable for the revolving door firms (1 if a revolving door firm, 0 if not) and controls for firm size (log of market value of equity), growth (book-to-market ratio and sales growth), financial condition (calculated as Zmijewski's (1984) distress score), significant asset acquisitions during the year ( 1 if yes, 0 if not), significant changes in debt or equity financing during the year ( 1 if yes, 0 if not), level of cash flow (measured as cash flow from operations), and year (we include yearly dummy variables). ${ }^{20}$

\footnotetext{
${ }^{19}$ All COMPUSTAT firms with available data are used to calculate DA, even if they were not included in our hiring samples or did not have all data available on the control variables to enable them to be used in the later regression analyses.

${ }^{20}$ These additional data requirements reduce our sample size for the regressions to 132 (130) revolving door firms and 2,230 $(2,205)$ non-revolving door firms at time $t$ (time $t+1)$.
} 
Results (untabulated) for the multivariate regressions at time $t$ and $t+1$ are consistent with the univariate results and indicate that levels of $D A$ are not significantly $(p>.25)$ associated with revolving door appointments either in the year of the hire or the following year. Specifically, both regression models are significant at $p<.0001$, yet the coefficient on the revolving door indicator variable is not significant in the $t$ regression $(t$-statistic $=1.12)$ or in the $t+1$ regression $(t$-statistic $=0.24)$. These collective results provide additional evidence that the revolving door hiring firms targeted by SOX do not report higher levels of DA after appointing the new individuals. In fact, we find that the levels of $D A$ are very similar between revolving door and non-revolving door hiring firms immediately after these appointments. ${ }^{21}$

\subsubsection{Subsequent AAERs}

To provide additional evidence on the quality of financial reporting subsequent to companies hiring personnel directly from their external audit firms, we examine the relationship between revolving door hires and the company's subsequent receipt of an AAER from the SEC. AAERs are issued for materially misleading financial statements and are typically issued only in cases of extremely egregious financial reporting behavior that usually involves some type of management fraud (Feroz, Park, \& Pastena , 1991). Prior studies have used them to directly assess the quality of financial reporting (Beasley, 1996; Bonner, Palmrose, \& Young, 1998). If the quality of financial reporting was significantly impaired due to revolving door appointments, we expect a positive association between revolving door appointments and the subsequent receipt of an AAER following the officer's appointment. We collect all AAERs issued from January 1985 to July 2006, which is four years after the sample period for the officer appointments. Within the sample, AAERs were issued to 93 companies subsequent to officers' appointment dates, but only one of these was issued to a company that had previously

\footnotetext{
${ }^{21}$ Assessing signed current discretionary accruals produces very similar results.
} 
made a revolving door appointment. Therefore, the AAER frequency is just $0.5 \%$ for revolving door appointments compared to $2.3 \%$ for non-revolving door appointments. Further, to control for other possible factors associated with the company's appointment, we estimate probit models that include the earlier company and appointee control variables. The dependent variables indicate whether the company receives an AAER within a four (five) year window subsequent to the officer's appointment date. ${ }^{22}$ Results of these probit models are reported in Table 7.

[INSERT TABLE 7 HERE]

The coefficients on REVOLVING_DOOR are negative and significant in both the fiveyear $(t$-statistic $=-2.31)$ and four-year $(t$-statistic $=-2.01)$ models. These results indicate that revolving door companies were significantly less likely to receive AAERs than were companies that did not hire officers directly from their audit firms. Of the control variables, we find that profitability $(R O A)$ and growth opportunities $(B M)$ have significant coefficients in one or both of the models. Therefore, a company was less likely to receive a future AAER if it was profitable or it had high growth opportunities in the year of the officer's appointment. While numerous other factors may contribute to a company's receipt of an AAER, these results provide additional evidence that revolving door appointments did not result in lower quality financial reporting as reflected in the subsequent receipt of an AAER.

\subsection{Additional tests}

\subsubsection{Job title}

\footnotetext{
${ }^{22}$ Probit models for the issuance of AAERs within three years give similar results to those reported in Table 7 for the four year and five year periods.
} 
We first examine whether the results are affected by the job title of the newly appointed officer. Since CFO appointments account for the majority of our sample, we partition the sample into 2,354 CFO appointments and 822 appointments to other positions (e.g., Controller, Treasurer, Chief Accounting Officer). We re-estimate the regression models on these two subgroups and the results are reported in Table 8. The results for the CFO sub-sample are very similar to those found in the full sample. The coefficient for REVOLVING_DOOR is positive and significant $(t$-statistic $=2.04 ; \mathrm{p}<.05)$ in the first regression, and the REVOLVING_DOOR*SMALL interaction term has a positive and significant coefficient ( $t$ statistic $=2.74 ; \mathrm{p}<.01)$ in the second regression. ${ }^{23}$ While these CFO findings are very consistent with the results in the full sample, the non-CFO results are statistically insignificant for both the REVOLVING_DOOR variable and the REVOLVING_DOOR*SMALL interaction variable. Accordingly, we find that the positive market reaction to revolving door hires is driven by the appointments of CFOs by small companies.

\section{[INSERT TABLE 8 HERE]}

\subsubsection{Officers that have prior CPA experience}

We re-estimate the models in Table 6 using only those officers that have prior CPA experience (thus, our estimation sample reduces to 1,162 hires). In these reduced sample regressions, the REVOLVING_DOOR coefficient remains positive and significant $(t$-statistic $=1.87)$ and the REVOLVING_DOOR*SMALL coefficient is also positive and significant $(t$-statistic $=2.55)$. Thus, our results are robust to examining only the officers that have previous CPA experience.

\footnotetext{
${ }^{23}$ Within the sub-sample of CFO appointments, there are 75 revolving door hires by small companies and 58 by large companies.
} 


\subsubsection{Company age, profitability and growth opportunities}

Table 5 indicates that the revolving hire companies are significantly younger, more profitable and have lower book-to-market ratios than the other types of hires. These findings are consistent with auditors having stronger incentives to join companies that have better future prospects. Thus, any signaling effect of a revolving door hire may be associated with the company's age, profitability or growth opportunities. To examine this argument, we test whether the positive market reaction to revolving door hires is stronger for companies that are young, profitable or have good growth opportunities. We first partition the sample into young and old companies by creating a dummy variable (AGEDUM) that equals one if the company is younger than the sample median (eight years). We then add AGEDUM and the REVOLVING_DOOR*AGEDUM interaction variable to the regression. We find that both the AGEDUM and REVOLVING_DOOR*AGEDUM coefficients are statistically insignificant ( $t$ statistics $=-0.24$ and -0.09 , respectively).

Next, we partition the sample into profitable and less profitable companies by creating a dummy variable (ROADUM) that equals one if the company's $R O A$ exceeds the sample median $(1.30 \%)$. We then add ROADUM and the REVOLVING_DOOR*ROADUM interaction variable to the regression. Whilst the ROADUM coefficient is positive and statistically significant $(t$-statistic $=2.31)$, the $R E V O L V I N G \_D O O R^{*} R O A D U M$ coefficient is insignificant $(t$-statistic $=-0.34)$

Finally, we partition the sample into high and low growth opportunities by creating a dummy variable (BMDUM) that equals one if the company's book-to-market ratio is below the sample median (0.43). We then add the BMDUM and a REVOLVING_DOOR* BMDUM interaction variable to the regression. We find that both the BMDUM and 
REVOLVING_DOOR ${ }^{*} B M D U M$ coefficients are statistically insignificant $(t$-statistic $=0.20$ and 0.92 , respectively).

Overall, these three sets of results do not support the view that any signaling effect of a revolving door hire is associated with the company's age, profitability or growth opportunities.

\subsubsection{Confounding events}

In order to determine that our results are not driven by other information that might have been released during our three-day event window (DeFond et al., 2005), we search for confounding events by examining whether the press releases that disclose officer appointments contain any other information that might affect the market reaction (e.g., the departure of an outgoing officer or the appointment of more than one officer). In addition, we search for all other press releases disclosed within the three-day event window. For the revolving door sample, we find possible confounding disclosures for 86 hires and no confounding disclosures for 107 hires. The mean CAR for the clean sample of 107 revolving door hires is $+1.69 \%$, which is statistically significant at $\mathrm{p}<.01(t$-statistic $=3.11)$. Moreover, within the revolving door hires we find no significant difference in mean CARs between the clean sample and the sample with confounding disclosures $(t$-statistic $=1.35)$.

It would be prohibitively costly to search for confounding events in the full sample of 3,176 hires. Instead, we match each revolving door appointment to a CPA experience hire and to a non-CPA experience hire, where the matching is by year of the appointment and company size (total assets). Thus, our matched samples contain 386 non-revolving door appointments $(386=2 * 193)$ and we search for confounding events within these matched samples. We create a dummy variable (CONFOUND), which equals one if there is a confounding disclosure in either the revolving door sample $(n=193)$ or the matched samples $(n=386)$. We then re- 
estimate the models in Table 6 using an estimation sample of 579 hires (193 revolving door + 386 non-revolving door) and include the CONFOUND variable as an additional control. We find that the REVOLVING_DOOR coefficient is positive and statistically significant ( $t$-statistic $=2.31)$ and that the REVOLVING_DOOR*SMALL interaction coefficient is positive and significant $(t$-statistic $=2.13)$ in our second regression. In addition, we then re-estimate the models in Table 6 using only the 339 appointments in which there are no confounding disclosures. In this smaller sample, the REVOLVING_DOOR coefficient remains significantly positive $(t$-statistic $=2.02)$ whereas the REVOLVING_DOOR*SMALL coefficient loses statistical significance $(t$-statistic $=1.63)$. In sum, these additional tests suggest that our significant market reaction results are not substantively driven by other disclosures during our examination period.

\subsubsection{Is there an advertising aspect to revolving door appointments?}

If there is an advertising aspect to revolving door appointments, we expect that companies would attempt to publicize these hires and that they would be disproportionately reported in newspapers such as the Wall Street Journal. Therefore, we investigate whether the appointments in the revolving door sample are more widely announced than in the two matched samples described in section 3.4.4 above. Of the 193 revolving door hires, we find that $50(25.9 \%)$ are reported in the Wall Street Journal and a total of $103(53.4 \%)$ are reported in a newspaper or trade publication within one week of the news wire release. Similarly, of the 386 matched hires, $108(28.0 \%)$ are reported in the Wall Street Journal and a total of 182 $(47.2 \%)$ are reported in a newspaper or trade publication. Separate tests indicate that these proportions are not significantly different between the two groups for either Wall Street Journal coverage $\left(\chi^{2}=0.279 ; \mathrm{p}=.60\right)$, or for all newspapers and trade journals $\left(\chi^{2}=1.99 ; \mathrm{p}=.16\right)$. 
Thus, we find no evidence that the revolving door firms were advertising their appointments any more than were the non-revolving door firms.

\subsubsection{Changes in profitability and company size during the appointment year}

In our main tests, the profitability $(R O A)$ and size $(\operatorname{Ln}(A S S E T S))$ variables are obtained from the fiscal year-end immediately after the officer's appointment date. We use these financial statements because some of the younger companies do not have financial statements available in the year before the officer's appointment. Specifically, 20 of our 193 revolving door appointments have missing data in the previous year and the mean CAR is $+4.01 \%$ for these 20 hires. Therefore, imposing the requirement of past financial statements would mean that we lose the observations where the positive market reaction is strongest, and this in turn would bias our results against $H_{1}$ and $H_{2}$.

Despite this limitation, we examine whether the revolving door sample is systematically different from the control sample in terms of the change in profitability and growth (the change in total assets) around the appointment date. We construct these change variables using ROA and $\operatorname{Ln}(A S S E T S)$ data from the fiscal year-end immediately before the officer's appointment to the fiscal year-end immediately after. We find that the change in profitability during the appointment year is not significantly different between the revolving door hires and other types of appointments $(t$-statistic $=0.17)$. However, the mean growth of the revolving door companies is significantly greater than the non-revolving door appointments $(t$-statistic $=2.89)$. This is consistent with our finding in Table 5 that auditors accept employment positions with companies that have better growth prospects (i.e., lower book-tomarket ratios). 


\subsubsection{Alternative metrics for market returns}

We assess whether the results are robust to using a different metric for market returns. Specifically, we recalculate cumulative abnormal returns using the equally-weighted market return in place of the value-weighted market return. Re-estimating the models in Table 6 , the REVOLVING_DOOR and REVOLVING_DOOR*SMALL coefficients are positive $(t$-statistics $=$ 1.60 and 2.36, respectively). We also recalculate cumulative abnormal returns using size decile portfolio returns, and again the REVOLVING_DOOR and REVOLVING_DOOR*SMALL coefficients remain positive ( $t$-statistics $=1.60$ and 2.47 , respectively).

\section{Conclusions}

This study investigates how the market reacts when companies announce the appointments of senior accounting and finance officers directly from their external audit firms. This auditor-toclient "revolving door" hiring practice is now prohibited by the Sarbanes-Oxley Act of 2002. While the practice received a lot of emphasis in the media, our results indicate that it occurred infrequently. Between 1985 and 2002, only 6.1 percent of financial reporting executives were hired directly from companies' external audit firms and the frequency was actually declining in the years leading up to SOX. We examine cumulative abnormal returns over a three day event window centered on the announcement date, and find no evidence that the market viewed revolving door hires negatively. Rather, we find that the market rewarded companies that were able to attract individuals from their external audit firms. Moreover, we find that companies were not rewarded for hiring individuals with CPA experience unless they were hired directly from the company's external audit firm. Although highly publicized company failures have involved revolving door hires, our results suggest that the hiring practice was not pervasive and, when it did occur, the market generally viewed revolving door hires favorably. Therefore, 
the SOX restriction on revolving door appointments may not be an important protection for shareholders.

We also find that the aggregate positive share price reaction is driven primarily by smaller companies. Prior to SOX, these companies were rewarded by the equity market for attracting auditors into senior accounting and finance positions. This is generally consistent with arguments that small companies would be more severely impacted by the SOX restriction on revolving door hires (ISB, 1999), and adds another dimension to recent discussions of the impact of SOX on smaller firms (Kelleher, 2006).

As with many event studies, we cannot fully determine the extent to which the market reaction is attributable to perceived economic benefits or to signaling. Nevertheless, the positive market reaction is noteworthy regardless of whether revolving door appointments are positive signals about companies' future prospects or they bring positive benefits to the hiring companies. To the extent that revolving door hires signaled the auditor's confidence in the company's future, the SOX ruling now prevents this valuable signaling mechanism. Importantly, we also find that companies making revolving door appointments reported similar levels of discretionary accounting accruals and were significantly less likely to receive AAERs after these appointments compared to other non-revolving door hiring companies. These findings do not support the view that the revolving door hires targeted by SOX had impaired financial reporting quality. Moreover, it is inconsistent with the proposition that the market reaction to revolving door appointments would have been negative in the absence of a positive signaling effect. To the extent that the positive market reaction is not attributable to signaling, the SOX ruling implies that companies can no longer benefit from recruiting their auditors as senior accounting and finance officers. Thus, our conclusion that the SOX hiring restriction 
does little to protect shareholders is unaffected by whether the positive market reaction is attributable to signaling.

While our study is the first to assess the effect of revolving door hires on shareholder wealth, we do not consider the impact on other stakeholders. For example, the restriction on revolving door appointments may adversely affect individual practicing auditors by limiting their employment opportunities. The restriction could also affect other stakeholders such as bondholders and public accounting firms. Additionally, our study only examines the market reaction to appointments of senior financial reporting officers because the SOX restriction applies only to these positions, even though revolving door hires are more common at junior positions. 


\section{References}

AICPA. (1978). Commission on Auditors' Responsibilities (The Cohen Report). Report, conclusions and recommendations. New York: American Institute of Certified Public Accountants.

Ashbaugh, H., LaFond, R , \& Mayhew, B. W. (2003). Do non-audit services compromise auditor independence? Further evidence. The Accounting Review 78(3), 611-640.

Becker, C. L., DeFond, M. L., Jiambalvo, J., \& Subramanyam, K.R. (1998). The effect of audit quality on earnings management. Contemporary Accounting Research 15(1), 124.

Beasley, M. S. (1996). An empirical analysis of the relation between the board of director composition and financial statement fraud. The Accounting Review 71(4), 443-465.

Beasley, M. S., Carcello, J. V., \& Hermanson, D. R. (2000). Should you offer a job to your external auditor? Journal of Corporate Accounting and Finance 11(4), 35-42.

Bonner, S.E., Palmrose, Z.-V., \& Young, S.M. (1998). Fraud type and auditor litigation: an analysis of SEC accounting and auditing enforcement releases. The Accounting Review 73(4), 503-532.

Brickley, J. A. (2003). Empirical research on CEO turnover and firm performance: A discussion. Journal of Accounting and Economics 36(1-3), 227-233.

Chang, H, Chen, J., Liao, W. M., \& Mishra, B. R. (2006). CEOs'/CFOs' swearing by the numbers: Does it impact share price of the firm? The Accounting Review 81(1), 1-27.

Chung, H.,, \& Kallapur, S. (2003). Client importance, non-audit fees, and abnormal accruals. The Accounting Review 78(4), 931-955.

Clikeman, P. (1998). Auditor independence: Continuing controversy. Ohio CPA Journal 57(2), 40-43.

DeFond, M., \&.Francis, J R. (2005). Auditing research after Sarbanes-Oxley. Auditing: A Journal of Practice and Theory 24(Supplement), 5-30.

DeFond, M., Hann, R N., \& Hu, X. (2005). Does the market value financial expertise on audit committees of boards of directors. Journal of Accounting Research 43(1), 153-193.

DeFond, M. L., \& Jiambalvo, J. (1994). Debt covenant violation and manipulation of accruals. Journal of Accounting and Economics 17(1), 145-176.

DeFond, M. L., \& Subramanyam, K. R. (1998). Auditor changes and discretionary accruals. Journal of Accounting and Economics 25(1), 35-67. 
Dowdell, T. D. Jr., \& Krishnan, J. (2004). Former audit firm personnel as CFOs: Effect on earnings management. Canadian Accounting Perspectives 3(1), 117-142.

Farrell, K. A., \& Hersch, P. L. (2005). Additions to corporate boards: The effect of gender. Journal of Corporate Finance 11(1), 85-106.

Feroz, E.H., Park, K., \& Pastena, V.S. (1991). The financial and market effects of the SEC's accounting and auditing enforcement releases. Journal of Accounting Research 29(1), $107-142$.

Gaver, J. J., \& Gaver, K. M. (1993). Additional evidence on the association between the investment opportunity set and corporate financing, dividends and compensation policies. Journal of Accounting and Economics 17(1), 125-160.

Geiger, M.A., North, D. S., \& O'Connell, B. T. (2005). The auditor-to-client revolving door and earnings management. Journal of Accounting, Auditing and Finance 20(1), $1-26$.

Geiger, M.A., \& North, D.S. (2006). Does hiring a new CFO change things? An investigation of changes in discretionary accruals. The Accounting Review 81(4), 781-809.

Geiger, M.A., \& Raghunandan, K. (2001). Bankruptcies, audit reports and the Reform Act. Auditing: A Journal of Practice and Theory 20(1), 187-196.

Herdman, R. K. 2001. Written testimony before the US House of Representatives subcommittee on Oversight and Investigation. December 12, 2001.

Hribar, P., \& Collins, D. (2002). Errors in estimating accruals: Implications for empirical research. Journal of Accounting Research 40(1), 193-228.

Independence Standards Board (ISB). (1999). Discussion Memorandum Employment with Audit Clients. New York: Independence Standards Board.

Independence Standards Board (ISB). (2000). Independence Standard No.3 Employment with Audit Clients. New York: Independence Standards Board.

Jones, J. (1991). Earnings management during import relief investigations. Journal of Accounting Research 29(2), 193-228.

Jubak, J. (2002). Companies whose boards need a scare. MSN Money Markets Personal Finance. Editorial at http:/www.thestreet.com/funds/jubak/10015517.html, April 3, 2002.

Kaplan, S E., \& Whitecotton, S. M. (2001). An examination of auditor's reporting intentions when another auditor is offered client employment. Auditing: A Journal of Practice \& Theory 20(1), 45-63. 
Kelleher, K. (2006). Start-ups slam into Sarbanes. TheStreet.com, March 29, http;//www.thestreet.com/markets/marketfeatures/10276156.html.

Lennox, C. (2005). Audit quality and executive officers' affiliations with CPA firms. Journal of Accounting and Economics 39, 201-231.

Levitt, A. (1998). The numbers game. Speech given at NYU Center for Law and Business, New York, September 28.

Mahoney, L. S., \& Roush, P. B. (1994). When an auditor changes sides. Management Accounting 76(9), 56-60.

Mautz, R. K., \& Sharaf, H. A. (1961). The Philosophy of Auditing. American Accounting Association, Sarasota, FL.

Menon, K., \& Williams, D. D. (2004). Former audit partners and abnormal accruals. The Accounting Review 79(4), 1095-1118.

Mian, S. (2001). On the choice and replacement of chief financial officers. Journal of Financial Economics 60, 143-175.

Pitt, H.L. (2002). Written testimony before the Senate Committee on Banking, Housing and Urban Affairs. March 21, 2002.

Private Securities Litigation Reform Act. (1995). Government Printing Office (GPO), Private Securities Litigation Reform Act. Public Law No. 104-67. Government Printing Office, Washington, D.C.

Securities and Exchange Commission (SEC), Office of the Chief Accountant. (2003). Application of the January 2003 Rules on Auditor Independence: Frequently Asked Questions. Office of the Chief Accountant. (Available at http://www.accountingweb.com/cgi-bin/item.cgi?id=97970).

Wright, C. (2005). Auditors' need for a cooling-off period. The CPA Journal 75(12), 24-29.

Zmijewski, M. (1984). Methodological issues related to the estimation of financial distress. Journal of Accounting Research 22(Supplement), 59-8. 


\section{TABLE 1}

\section{Sample Composition}

Panel A: Accounting and finance officers hired / not hired from the company's own audit firm

“Revolving Door" Hires (the officer is hired from the company's own audit firm).

“Non-Revolving Door” Hires (the officer is not hired from the company's own audit firm).

\begin{tabular}{|rrr} 
& Observations & \% of sample \\
& 193 & $6.1 \%$ \\
Total & 2,983 & $93.9 \%$ \\
3,176 & $100.0 \%$
\end{tabular}

Panel B: Accounting and finance officers with / without prior CPA experience

“CPA Experience” Hires (the officer previously worked for an audit firm).

“No CPA Experience” Hires (the officer did not previously work for an audit firm).

\begin{tabular}{|rrr} 
& Observations & \% of sample \\
& 1,141 & $35.9 \%$ \\
Total & 2,035 & $64.1 \%$ \\
3,176 & $100.0 \%$
\end{tabular}

Panel C: Accounting and finance officers that were / were not former CPA partners

"Partner" Hires (the officer was previously a partner at an audit firm).

“Non-Partner” Hires (the officer was not previously a partner at an audit firm).

$\begin{array}{rrr} & \text { Observations } & \text { \% of sample } \\ & 260 & 8.2 \% \\ \text { Total } & 2,916 & 91.8 \% \\ & 3,176 & 100.0 \% \\ & & \\ & & \\ & \text { Observations } & \text { \% of sample } \\ & 575 & 18.1 \% \\ & 508 & 16.0 \% \\ & 806 & 25.4 \% \\ \text { Total } & 483 & 15.2 \% \\ & 804 & 25.3 \% \\ & 3,176 & 100.0 \%\end{array}$

Panel D: Companies’ audit firms

Arthur Andersen

Deloitte \& Touche

Ernst \& Young

KPMG

PricewaterhouseCoopers

Total 
TABLE 2

Distribution of Accounting/Finance Officer Hires

\begin{tabular}{rrrr}
\hline Year & Total Hires & Revolving Door Hires & \% Revolving Door Hires \\
1985 & 37 & 3 & $8.1 \%$ \\
1986 & 37 & 3 & $8.1 \%$ \\
1987 & 31 & 2 & $6.5 \%$ \\
1988 & 23 & 2 & $8.7 \%$ \\
1989 & 55 & 4 & $7.3 \%$ \\
1990 & 123 & 8 & $6.5 \%$ \\
1991 & 123 & 11 & $8.9 \%$ \\
1992 & 159 & 15 & $9.4 \%$ \\
1993 & 13 & $7.3 \%$ \\
1994 & 251 & 20 & $8.0 \%$ \\
1995 & 160 & $11.3 \%$ \\
1996 & 18 & $9.7 \%$ \\
1997 & 238 & 23 & $6.4 \%$ \\
1998 & 266 & 17 & $5.8 \%$ \\
1999 & 277 & 16 & $4.3 \%$ \\
2000 & 279 & 12 & $3.2 \%$ \\
2001 & 349 & 11 & $2.4 \%$ \\
2002 & 370 & 9 & $2.7 \%$ \\
\hline
\end{tabular}

The sample period begins at $1^{\text {st }}$ January, 1985 and it ends on $31^{\text {st }} \mathrm{July}, 2002$. 


\section{TABLE 3}

Three-Day [-1 to +1] Cumulative Abnormal Returns (CAR).

Day 0 is the date that the appointment of the accounting/finance officer is first announced.

Panel A: Descriptive statistics for the full sample $(N=3,176)$

“Revolving Door” Hires $(\mathrm{N}=193)$

“Non-revolving Door” Hires $(\mathrm{N}=\mathbf{2 , 9 8 3})$

“Revolving Door” Hires by Small Companies ( $\mathrm{N}=97)$

“Revolving Door” Hires by Large Companies $(\mathrm{N}=96)$

“Non-revolving Door” Hires by Small Companies $(\mathrm{N}=1,493)$

“Non-revolving Door” Hires by Large Companies $(\mathrm{N}=1,490)$

\section{Mean CAR}

(two-tailed $p$-value)

$+0.002$

$(0.074)$

Mean $C A R$

Median CAR

(two-tailed $p$-value) (two-tailed $p$-value)

$+0.012$

(0.002)

$+0.001$

$(0.267)$

$+0.022$

$(0.001)$

$+0.002$

$(0.646)$

$+0.002$

$(0.309)$

$+0.001$

(0.617)

$\begin{array}{rll}+0.006 & -0.077 & +0.131 \\ (0.084) & & \\ -0.001 & -0.114 & +0.130 \\ (0.421) & & \\ +0.017 & -0.079 & +0.131 \\ (0.008) & & \\ -0.001 & -0.072 & +0.088 \\ (0.919) & & \\ -0.002 & -0.114 & +0.131 \\ (0.352) & & \\ -0.000 & -0.092 & +0.101 \\ (0.856) & & \end{array}$

$5 \% \quad 95 \%$ percentile percentile

$-0.114+0.131$

$5 \% \quad 95 \%$ ercentile percentile ( 


\section{TABLE 3 (contd.)}

Panel C: CPA Experience Versus No CPA Experience Hires

“CPA Experience” Hires $(\mathrm{N}=1,141)$

“No CPA Experience” Hires $(\mathrm{N}=2,035)$

\section{“CPA Experience” Hires by Small Companies $(\mathrm{N}=645)$}

“CPA Experience” Hires by Large Companies $(\mathrm{N}=496)$

“No CPA Experience” Hires by Small Companies ( $\mathbf{N}=945)$

“No CPA Experience” Hires by Large Companies $(N=1,090)$
Mean CAR

(two-tailed $p$-value)

$+0.002$

$(0.171)$

$+0.002$

$(0.233)$

$+0.003$

(0.199)

$+0.001$

$(0.589)$

$+0.003$

$(0.204)$

$+0.001$

$(0.731)$
Median CAR

(two-tailed $p$-value)

$+0.001$

(0.679)

$-0.001$

(0.451)

$+0.001$

(0.637)

$+0.000$

(0.964)

$-0.001$

(0.474)

$-0.001$

$(0.739)$
$5 \%$

95\%

percentile percentile

\author{
$-0.114$ \\ 0.131
}

$-0.108$

0.128

$-0.114$

$+0.131$

$-0.100+0.101$

$-0.114+0.131$

$-0.088+0.099$

The $p$-values for the mean CARs are obtained under the hypothesis that the means are zero. The $p$-values for the median CARs are obtained under the hypothesis that the proportions of positive (negative) signs are one-half. The "revolving door" sample consists of officers who are hired directly from companies' own audit firms. The "CPA experience" sample consists of officers who previously worked for audit firms. A company is classified as small (large) if total assets are less (greater) than the median value in the full sample (i.e., \$205.20 million).

Variable definitions:

$C A R=\sum_{t=-1}^{t=+1} M A R_{t}$ where $M A R_{t}=\frac{1}{N_{t}} \sum_{i=1}^{N_{t}} A R_{i t}$ and $A R_{i t}=R_{i t}-E\left(R_{i t}\right)$ and $\mathrm{t}=-1,0,+1 . R_{i t}=$ the return of company $\mathrm{i}$ on day $\mathrm{t}$. $E\left(R_{i t}\right)=$ the return of the value-weighted market portfolio on day t. Cumulative abnormal returns are winsorized at the $5 \%$ and $95 \%$ percentiles in order to control for outliers. 


\section{TABLE 4}

Correlation Matrix for the Independent Variables ( $p$-values in parentheses)

\begin{tabular}{|c|c|c|c|c|c|c|c|c|c|}
\hline & & & & & & & & & \\
\hline 1. REVOLVING_DOOR & $\begin{array}{l}1 . \\
1.000 \\
(.)\end{array}$ & 2. & 3. & 4. & 5. & 6. & 7. & 8. & 9. \\
\hline 2. $\operatorname{Ln}($ ASSETS) & $\begin{array}{l}0.002 \\
(0.891)\end{array}$ & $\begin{array}{l}1.000 \\
(.)\end{array}$ & & & & & & & \\
\hline 3. $\operatorname{Ln}(A G E)$ & $\begin{array}{l}-0.066 \\
(0.000)\end{array}$ & $\begin{array}{l}0.454 \\
(0.000)\end{array}$ & $\begin{array}{l}1.000 \\
(.)\end{array}$ & & & & & & \\
\hline 4. $R O A$ & $\begin{array}{l}0.058 \\
(0.001)\end{array}$ & $\begin{array}{l}0.400 \\
(0.000)\end{array}$ & $\begin{array}{l}0.218 \\
(0.000)\end{array}$ & $\begin{array}{l}1.000 \\
(.)\end{array}$ & & & & & \\
\hline 5. LEVERAGE & $\begin{array}{l}0.029 \\
(0.103)\end{array}$ & $\begin{array}{l}0.285 \\
(0.000)\end{array}$ & $\begin{array}{l}0.133 \\
(0.000)\end{array}$ & $\begin{array}{l}0.031 \\
(0.077)\end{array}$ & $\begin{array}{l}1.000 \\
(.)\end{array}$ & & & & \\
\hline 6. $B M$ & $\begin{array}{l}-0.043 \\
(0.015)\end{array}$ & $\begin{array}{l}0.051 \\
(0.000)\end{array}$ & $\begin{array}{l}0.100 \\
(0.000)\end{array}$ & $\begin{array}{l}-0.099 \\
(0.000)\end{array}$ & $\begin{array}{l}0.093 \\
(0.000)\end{array}$ & $\begin{array}{l}1.000 \\
(.)\end{array}$ & & & \\
\hline 7. $\mathrm{CFO}$ & $\begin{array}{l}-0.030 \\
(0.088)\end{array}$ & $\begin{array}{l}-0.293 \\
(0.000)\end{array}$ & $\begin{array}{l}-0.246 \\
(0.000)\end{array}$ & $\begin{array}{l}-0.154 \\
(0.000)\end{array}$ & $\begin{array}{l}-0.101 \\
(0.000)\end{array}$ & $\begin{array}{l}-0.005 \\
(0.776)\end{array}$ & $\begin{array}{l}1.000 \\
\text { (.) }\end{array}$ & & \\
\hline 8. FEMALE & $\begin{array}{l}-0.009 \\
(0.608)\end{array}$ & $\begin{array}{l}0.024 \\
(0.183)\end{array}$ & $\begin{array}{l}0.030 \\
(0.087)\end{array}$ & $\begin{array}{l}-0.006 \\
(0.753)\end{array}$ & $\begin{array}{l}-0.017 \\
(0.351)\end{array}$ & $\begin{array}{l}0.001 \\
(0.964)\end{array}$ & $\begin{array}{l}-0.111 \\
(0.000)\end{array}$ & $\begin{array}{l}1.000 \\
(.)\end{array}$ & \\
\hline 9. CPA_EXPERIENCE & $\begin{array}{l}0.340 \\
(0.000)\end{array}$ & $\begin{array}{l}-0.111 \\
(0.000)\end{array}$ & $\begin{array}{l}-0.066 \\
(0.000)\end{array}$ & $\begin{array}{l}0.000 \\
(0.993)\end{array}$ & $\begin{array}{l}-0.010 \\
(0.562)\end{array}$ & $\begin{array}{l}-0.025 \\
(0.158)\end{array}$ & $\begin{array}{l}0.075 \\
(0.000)\end{array}$ & $\begin{array}{l}-0.005 \\
(0.771)\end{array}$ & $\begin{array}{l}1.000 \\
(.)\end{array}$ \\
\hline 10. PARTNER & $\begin{array}{l}0.477 \\
(0.000) \\
\end{array}$ & $\begin{array}{l}0.078 \\
(0.000) \\
\end{array}$ & $\begin{array}{l}-0.030 \\
(0.087) \\
\end{array}$ & $\begin{array}{l}0.035 \\
(0.051) \\
\end{array}$ & $\begin{array}{l}0.028 \\
(0.111) \\
\end{array}$ & $\begin{array}{l}-0.044 \\
(0.014) \\
\end{array}$ & $\begin{array}{l}0.032 \\
(0.069) \\
\end{array}$ & $\begin{array}{l}-0.052 \\
(0.003)\end{array}$ & $\begin{array}{l}0.0399 \\
(0.000) \\
\end{array}$ \\
\hline
\end{tabular}

Variable definitions:

REVOLVING_DOOR $=$ one if the accounting/finance officer is hired from the company's external audit firm (zero otherwise). ASSETS = Total assets ( $\$$ million). AGE = Company's age measured as the number of years that the company is recorded on Compustat. ROA $=$ Net income / total assets. LEVERAGE = Total debt / total assets. $B M=$ book-to-market ratio (market values are measured at the end of the month preceding the officer's appointment date; book values are measured at the end of the fiscal year). $C F O=$ one if the newly appointed accounting/finance officer has the title Chief Financial Officer (zero otherwise). FEMALE = one if the newly appointed accounting/finance officer is female (zero otherwise). CPA EXPERIENCE = one if the accounting/finance officer previously worked for an audit firm (zero otherwise). PARTNER = one if the newly appointed accounting/finance officer was formerly a partner or senior partner at an audit firm 
(zero otherwise). The continuous variables are winsorized at the 5\% and 95\% percentiles in order to control for outliers. 
TABLE 5

Characteristics of the "Revolving Door" and "Non-Revolving Door" Hires

Ln(ASSETS)

Mean

\author{
"Revolving \\ Door" Hires \\ $(\mathrm{N}=193)$
}

Std. dev.

Ln(AGE)

Mean

Std. dev.

$R O A$

Mean

Std. dev.

LEVERAGE

Mean

Std. dev.

$B M$

Mean

Std. dev.

CFO

Mean

Std. dev.

FEMALE

Mean

Std. dev.
5.495

1.937

2.004

1.946

$-0.032$

0.190

0.264

0.206

0.489

0.455

0.689

0.464

0.078

0.268

\author{
"Non-Revolving \\ Door" Hires \\ $(\mathrm{N}=\mathbf{2 , 9 8 3})$
}

5.477

1.772

2.251

0.889

$-0.091$

0.245

0.239

0.208

0.581

0.518

0.745

0.436

0.089

0.284
Tests for significant

differences in means

$$
t \text {-statistic }=0.14
$$

$t$-statistic $=-3.70 * * *$

$t$-statistic $=3.26^{* * *}$

$t$-statistic $=1.63$

$t$-statistic $=-2.43^{* *}$

$t$-statistic $=-1.70^{*}$

$t$-statistic $=-0.51$

*** Significant at the 1\% level (two-tailed). ** Significant at the 5\% level (two-tailed). * Significant at the $10 \%$ level (two-tailed).

Variable definitions:

ASSETS $=$ Total assets ( $\$$ million). AGE = Company's age measured as the number of years that the company is recorded on Compustat. $R O A=$ Net income / total assets. LEVERAGE = Total debt $/$ total assets. $B M=$ book-to-market ratio (market values are measured at the end of the month preceding the officer's appointment date; book values are measured at the end of the fiscal year). $C F O=$ one if the newly appointed accounting/finance officer has the title Chief Financial Officer (zero otherwise). FEMALE = one if the newly appointed accounting/finance officer is female (zero otherwise). The continuous variables are winsorized at the $5 \%$ and $95 \%$ percentiles in order to control for outliers. 


\section{TABLE 6}

Multivariate Regressions of Three-Day Cumulative Abnormal Returns (CAR), (t-statistics are shown in parentheses)

$\begin{array}{lcc}\text { REVOLVING_DOOR } & 0.010 & -0.001 \\ \text { REVOLVING_DOOR * SMALL } & (2.02)^{* *} & (-0.24) \\ & & 0.020 \\ \text { SMALL } & & (2.49)^{* *} \\ & & 0.004 \\ \text { Ln(ASSETS) } & -0.001 & (1.48) \\ \text { Ln(AGE) } & (-1.31) & \\ \text { ROA } & 0.001 & 0.001 \\ & (0.49) & (0.65) \\ \text { LEVERAGE } & 0.015 & 0.014 \\ & (2.66)^{* * *} & (2.71)^{* * *} \\ \text { BM } & -0.008 & -0.007 \\ & (-1.44) & (-1.34) \\ \text { CFO } & 0.003 & 0.003 \\ & (1.41) & (1.43) \\ \text { FEMALE } & -0.001 & -0.002 \\ \text { CPA_EXPERIENCE } & (-0.60) & (-0.65) \\ \text { PARTNER } & 0.000 & -0.000 \\ \text { Intercept } & (0.00) & (-0.04) \\ & -0.002 & -0.002 \\ \text { Observations } & (-0.67) & (-0.80) \\ \mathrm{R}^{2}(\%) & 0.003 & 0.006 \\ \end{array}$

*** Significant at the $1 \%$ level (two-tailed). $* *$ Significant at the $5 \%$ level (two-tailed). The standard errors are adjusted for multiple observations relating to a given company.

Variable definitions:

$C A R=\sum_{t=-1}^{t=+1} M A R_{t}$ where $M A R_{t}=\frac{1}{N_{t}} \sum_{i=1}^{N_{t}} A R_{i t}$ and $A R_{i t}=R_{i t}-E\left(R_{i t}\right)$ and $\mathrm{t}=-1,0$, $+1 . R_{i t}=$ the return of company $\mathrm{i}$ on day t. $E\left(R_{i t}\right)=$ the return of the value-weighted market portfolio on day t. REVOLVING_DOOR = one if the accounting/finance officer is hired from the company's external audit firm (zero otherwise). ASSETS $=$ Total assets ( $\$$ million). $A G E=$ Company's age measured as the number of years that the company is recorded on Compustat. $R O A=$ Net income $/$ total assets. $L E V E R A G E=$ Total debt $/$ total 
assets. $B M=$ book-to-market ratio (market values are measured at the end of the month preceding the officer's appointment date; book values are measured at the end of the fiscal year). $C F O=$ one if the newly appointed accounting/finance officer has the title Chief Financial Officer (zero otherwise). FEMALE = one if the newly appointed accounting/finance officer is female (zero otherwise). CPA_EXPERIENCE $=$ one if the accounting/finance officer previously worked for an audit firm (zero otherwise). PARTNER = one if the newly appointed accounting/finance officer was formerly a partner or senior partner at an audit firm (zero otherwise). The continuous variables are winsorized at the $5 \%$ and $95 \%$ percentiles in order to control for outliers. 


\section{TABLE 7}

Accounting and Auditing Enforcement Releases (AAERs) Issued Subsequent to the Appointments of Accounting and Finance Officers. (z-statistics are shown in parentheses)

\begin{tabular}{lcc}
\hline & \multicolumn{2}{c}{ An AAER issued within: } \\
\cline { 2 - 3 } REVOLVING_DOOR & $\underline{5 \text { years }}$ & $\underline{4 \text { years }}$ \\
& -0.784 & -0.688 \\
Ln(ASSETS) & $(-2.31)^{* *}$ & $(-2.01)^{* *}$ \\
& 0.017 & 0.012 \\
Ln(AGE) & $(0.44)$ & $(0.28)$ \\
ROA & -0.009 & 0.006 \\
& $(-0.12)$ & $(0.08)$ \\
LEVERAGE & -0.491 & -0.479 \\
BM & $(-2.31)^{* *}$ & $(-1.92)^{*}$ \\
CFO & 0.220 & 0.141 \\
& $(0.84)$ & $(0.51)$ \\
FEMALE & 0.133 & 0.216 \\
CPA_EXPERIENCE & $(1.43)$ & $(2.22)^{* *}$ \\
PARTNER & 0.006 & -0.072 \\
Intercept & $(0.04)$ & $(-0.55)$ \\
& 0.020 & -0.035 \\
Observations & $(0.11)$ & $(-0.19)$ \\
Pseudo R $\left.{ }^{2} \%\right)$ & 0.135 & 0.151 \\
& $(1.25)$ & $(1.31)$ \\
& 0.040 & 0.059 \\
& $(0.20)$ & $(0.28)$ \\
& -2.222 & -2.303 \\
& $(-8.27)^{* * *}$ & $(-7.61)^{* * *}$ \\
& & \\
& 3,176 & 3,176 \\
& 2.65 & 3.15 \\
\hline
\end{tabular}

*** Significant at the 1\% level (two-tailed). ** Significant at the 5\% level (twotailed). * Significant at the $10 \%$ level (two-tailed). The models are estimated using probit and the standard errors are adjusted for multiple observations relating to a given company.

Variable definitions:

$A A E R=$ one if the company receives an Accounting and Auditing Enforcement Release within a five year period (four year period) following the appointment date of the accounting and finance officer (zero otherwise). REVOLVING_DOOR $=$ one if the accounting/finance officer is hired from the company's external audit firm (zero otherwise). ASSETS $=$ Total assets ( $\$$ million). $A G E=$ Company's age measured as the number of years that the company is recorded on Compustat. $R O A=$ Net income $/$ total assets. $L E V E R A G E=$ Total debt $/$ total assets. $B M=$ book-to-market ratio (market 
values are measured at the end of the month preceding the officer's appointment date; book values are measured at the end of the fiscal year). $C F O=$ one if the newly appointed accounting/finance officer has the title Chief Financial Officer (zero otherwise). FEMALE = one if the newly appointed accounting/finance officer is female (zero otherwise). CPA_EXPERIENCE $=$ one if the accounting/finance officer previously worked for an audit firm (zero otherwise). PARTNER = one if the newly appointed accounting/finance officer was formerly a partner or senior partner at an audit firm (zero otherwise). The continuous variables are all winsorized at the $5 \%$ and $95 \%$ percentiles in order to control for outliers. The continuous variables are winsorized at the $5 \%$ and $95 \%$ percentiles in order to control for outliers. 


\section{TABLE 8}

Multivariate Regressions of Three-Day Cumulative Abnormal Returns (CAR) For CFOs and non-CFOs (t-statistics are shown in parentheses)

\begin{tabular}{|c|c|c|c|c|}
\hline \multirow[b]{2}{*}{ REVOLVING_DOOR } & \multicolumn{2}{|c|}{ CFO sub-sample $(C F O=1)$} & \multicolumn{2}{|c|}{ Non-CFO sub-sample $(C F O=0)$} \\
\hline & $\begin{array}{l}0.013 \\
(2.04)^{* *}\end{array}$ & $\begin{array}{l}-0.004 \\
(-0.52)\end{array}$ & $\begin{array}{r}0.003 \\
(0.42)\end{array}$ & $\begin{array}{r}0.002 \\
(0.23)\end{array}$ \\
\hline REVOLVING_DOOR * SMALL & & $\begin{array}{l}0.027 \\
(2.74)^{* * *}\end{array}$ & & $\begin{array}{l}0.002 \\
(0.18)\end{array}$ \\
\hline$S M A L L$ & & $\begin{array}{l}0.005 \\
(1.80)^{*}\end{array}$ & & $\begin{array}{l}-0.002 \\
(-0.33)\end{array}$ \\
\hline Ln(ASSETS) & $\begin{array}{l}-0.001 \\
(-1.64)^{*}\end{array}$ & & $\begin{array}{r}0.000 \\
(0.30)\end{array}$ & \\
\hline $\operatorname{Ln}(A G E)$ & $\begin{array}{l}0.001 \\
(0.49)\end{array}$ & $\begin{array}{l}0.001 \\
(0.62)\end{array}$ & $\begin{array}{l}0.000 \\
(0.14)\end{array}$ & $\begin{array}{r}0.000 \\
(0.18)\end{array}$ \\
\hline$R O A$ & $\begin{array}{l}0.018 \\
(2.97)^{* * *}\end{array}$ & $\begin{array}{l}0.017 \\
(2.99)^{* * *}\end{array}$ & $\begin{array}{l}-0.003 \\
(-0.22)\end{array}$ & $\begin{array}{l}-0.003 \\
(-0.21)\end{array}$ \\
\hline LEVERAGE & $\begin{array}{l}-0.007 \\
(-1.09)\end{array}$ & $\begin{array}{l}-0.006 \\
(-1.00)\end{array}$ & $\begin{array}{l}-0.011 \\
(-1.05)\end{array}$ & $\begin{array}{l}-0.011 \\
(-1.04)\end{array}$ \\
\hline$B M$ & $\begin{array}{l}0.004 \\
(1.40)\end{array}$ & $\begin{array}{r}0.004 \\
(1.38)\end{array}$ & $\begin{array}{r}0.002 \\
(0.40)\end{array}$ & $\begin{array}{l}0.002 \\
(0.40)\end{array}$ \\
\hline FEMALE & $\begin{array}{l}-0.003 \\
(-0.66)\end{array}$ & $\begin{array}{l}-0.004 \\
(-0.74)\end{array}$ & $\begin{array}{l}0.004 \\
(0.88)\end{array}$ & $\begin{array}{l}0.004 \\
(0.90)\end{array}$ \\
\hline CPA_EXPERIENCE & $\begin{array}{l}-0.002 \\
(-0.70)\end{array}$ & $\begin{array}{l}-0.003 \\
(-0.85)\end{array}$ & $\begin{array}{r}0.000 \\
(0.03)\end{array}$ & $\begin{array}{r}0.000 \\
(0.00)\end{array}$ \\
\hline PARTNER & $\begin{array}{r}0.003 \\
(0.50)\end{array}$ & $\begin{array}{r}0.006 \\
(1.03)\end{array}$ & $\begin{array}{r}0.004 \\
(0.50)\end{array}$ & $\begin{array}{r}0.005 \\
(0.56)\end{array}$ \\
\hline Intercept & $\begin{array}{c}0.009 \\
(1.78)^{*}\end{array}$ & $\begin{array}{l}-0.002 \\
(-0.48)\end{array}$ & $\begin{array}{r}0.000 \\
(0.02)\end{array}$ & $\begin{array}{r}0.003 \\
(0.40)\end{array}$ \\
\hline $\begin{array}{l}\text { Observations } \\
\mathrm{R}^{2}(\%)\end{array}$ & $\begin{array}{r}2,354 \\
0.92\end{array}$ & $\begin{array}{r}2,354 \\
1.28\end{array}$ & $\begin{array}{r}822 \\
0.38\end{array}$ & $\begin{array}{r}822 \\
0.39\end{array}$ \\
\hline
\end{tabular}




\section{TABLE 8 (contd.)}

*** Significant at the $1 \%$ level (two-tailed). ** Significant at the $5 \%$ level (two-tailed). $*$ Significant at the $10 \%$ level (two-tailed). The standard errors are adjusted for multiple observations relating to a given company.

\section{Variable definitions:}

$C A R=\sum_{t=-1}^{t=+1} M A R_{t}$ where $M A R_{t}=\frac{1}{N_{t}} \sum_{i=1}^{N_{t}} A R_{i t}$ and $A R_{i t}=R_{i t}-E\left(R_{i t}\right)$ and $\mathrm{t}=-1,0,+1 . R_{i t}=$ the return of company $\mathrm{i}$ on day t. $E\left(R_{i t}\right)=$ the return of the value-weighted market portfolio on day t. $A A E R=$ one if the company receives an Accounting and Auditing Enforcement Release within a five year period (four year period) following the appointment date of the accounting and finance officer (zero otherwise). REVOLVING_DOOR $=$ one if the accounting/finance officer is hired from the company's external audit firm (zero otherwise). ASSETS = Total assets ( $\$$ million). AGE = Company's age measured as the number of years that the company is recorded on Compustat. $R O A=$ Net income / total assets. $L E V E R A G E=$ Total debt / total assets. $B M=$ book-to-market ratio (market values are measured at the end of the month preceding the officer's appointment date; book values are measured at the end of the fiscal year). $C F O=$ one if the newly appointed accounting/finance officer has the title Chief Financial Officer (zero otherwise). FEMALE $=$ one if the newly appointed accounting/finance officer is female (zero otherwise). CPA_EXPERIENCE $=$ one if the accounting/finance officer previously worked for an audit firm (zero otherwise). PARTNER $=$ one if the newly appointed accounting/finance officer was formerly a partner or senior partner at an audit firm (zero otherwise). The continuous variables are all winsorized at the $5 \%$ and $95 \%$ percentiles in order to control for outliers. The continuous variables are winsorized at the $5 \%$ and $95 \%$ percentiles in order to control for outliers. 


\section{$\underline{\text { Appendix }}$}

Senior Audit Manager of Deloitte \& Touche Joins L. L. Knickerbocker as Vice President/Corporate Controller

444 words

6 July 1998

08:47 am

PR Newswire

English

(c) 1998 PR Newswire

LAKE FOREST, Calif., June 6 /PRNewswire/ -- The L. L. Knickerbocker Co., Inc. (Nasdaq: KNIC) announced today that Terry L. Gardy, Senior Audit Manager of Deloitte \& Touche LLP, has accepted a position as Vice President/Corporate Controller, effective immediately.

Ms. Gardy has been with Deloitte \& Touche for ten years, moving up the ranks from Senior Accountant in 1988 to Audit Manager in 1993 to her present position. She has managed multiple financial statement audit engagements of both public and private companies, performing acquisition audits and due diligence procedures, and has resolved purchase accounting issues. Ms. Gardy has served as Senior Audit Manager on behalf of Deloitte \& Touche for The L. L. Knickerbocker Company, having performed three of the Company's audits beginning with the year 1995 .

Louis L. Knickerbocker, Chairman \& CEO, said "Completing an audit for The L. L. Knickerbocker Company requires the review and audit of five separate corporations in the U.S. and Asia. A difficult and complex job. Ms. Gardy managed these audits during the years of the Company's acquisition program, financing and growth. She is completely conversant with our core business and our investments division. We are happy to have her on board."

"We are very pleased with Terry Gardy's decision to join The L. L. Knickerbocker Company. Ms. Gardy has a deep understanding of the Company. Through her involvement in the last three audits with the international accounting firm of Deloitte \& Touche and, as we continue to expand worldwide, her outstanding technical skills will round out LLK's worldwide financial team," said Anthony Shutts, Chief Financial Officer. 
Wolverine Tube names James E. Deason executive vice president, finance and administration

241 words

15 September 1994

Business Wire

English

(Copyright (c) 1994, Business Wire)

HUNTSVILLE, Ala.--(BUSINESS WIRE)--Sept. 15, 1994--Wolverine Tube, Inc. (NYSE:WLV) today announced that James E. (Jed) Deason has been appointed Executive Vice President, Finance and Administration.

Deason (47), a Certified Public Accountant, was most recently a partner with Ernst \& Young in Birmingham, Alabama. Deason earned a B.S. degree in Business Administration from Jacksonville State University and a M.A. degree in Accounting from the University of Alabama.

Commenting on the announcement, John M. Quarles, chairman, president and chief executive officer, said, "We are extremely pleased to have Mr. Deason join our company. Jed brings to Wolverine 20 years of 'Big 6' public accounting and financial experience having worked with a broad range of private and public companies in technology, healthcare and manufacturing. He has been the audit partner on the Wolverine account for the past five years and is well qualified to assume the responsibilities this position entails. We look forward to his contribution to Wolverine." 